\title{
The Sunnfjord Melange, evidence of Silurian ophiolite accretion in the West Norwegian Caledonides
}

\author{
T. B. ANDERSEN ${ }^{1}$, K. P. SKJERLIE ${ }^{2}$ \& H. FURNES ${ }^{2}$ \\ ${ }^{1}$ Institutt for Geologi, Universitetet i Oslo. P. Box 1047. 0316 Blindern, Oslo 3, Norway \\ ${ }^{2}$ Geologisk Institutt Avd. A., Allégt. 41, 5007 Bergen-Universitet, Norway
}

\begin{abstract}
A major composite terrane, the Sunnfjord Melange, has been identified in the West Norwegian Caledonides. The rocks of the melange provide a terrane-link between the allochthonous continental rocks of the Dalsfjord Suite with its cover of continental margin deposits and the oceanic terrane of the Solund-Stavfjord Ophiolite Complex. The melange was formed as the ophiolite was emplaced on the the fossiliferous Lower to Middle Silurian continental margin deposits of the Herland Group. This group unconformably overlies older metasedimentary rocks of the Høyvik Group and the crystalline basement of the Dalsfjord Suite. A structural style characteristic of thin-skinned thrustfoldbelts is locally preserved within the Herland Group on Atløy, and the thrust-foldbelt was developed in the foreland of the continental margin during the ophiolite accretion. $\mathrm{A} \mathrm{U}-\mathrm{Pb}$ zircon age of $443 \pm 3 \mathrm{Ma}$ from the ophiolite, the Silurian fossils in the Herland Group and the identification of the Sunnfjord Melange as an obduction melange provide the basis for a well constrained model of ophiolite accretion in the Scandinavian Caledonides.
\end{abstract}

Detailed structural studies combined with recent stratigraphical, geochronological and geochemical studies (Brekke \& Solberg 1987; Berg 1988; Dunning \& Pedersen 1988; Skjerlie 1988; Skjerlie et al. in press) in the Sunnfjord region, W. Norway (Fig. 1), permit the presentation of a model where the timing and kinematics of ophiolite accretion in the Scandinavian Caledonides can be constrained. On the basis of its relationships to the fossiliferous rocks in the Brurestakken area on Atløy, the Solund-Stavfjord Ophiolite Complex (Furnes et al. 1981) can be shown to have been accreted during the Silurian. The emplacement of the ophiolite is recorded by the development of a major obduction melange which can be mapped along strike for a distance of approximately $60 \mathrm{~km}$ from Tviberg in the south to west of Askrova in the north (Fig. 1). Brekke \& Solberg (1987) assigned the rocks of the melange partly to the Herland Group and partly to Solund-Stavfjord Ophiolite Complex (Staveneset Group, Fig. 2). In accordance with the revised interpretation of these rocks, however, we propose a new stratigraphic unit, the Sunnfjord Melange.

The obducted Solund-Stavfjord Ophiolite Complex has previously been regarded as one of a group of ophiolites (Group I) thought to be of Cambrian age (Sturt et al. 1984). Zircons from the Solund-Stavfjord Ophiolite Complex, however, have yielded a U-Pb age of $443 \pm 3 \mathrm{Ma}$ (Dunning \& Pedersen 1988). Field relationships on Tviberg (Fig. 1) show that the dated rocks represent an older part of the ophiolite which is truncated by shear zones and a younger set of spreading-related dykes (Skjerlie 1988; Skjerlie et al. 1989). In spite of the uncertainties involved in correlating stratigraphical and isotopic ages, we base our discussion on the time-scale by McKerrow et al. (1985), and suggest that the Solund-Stavfjord Ophiolite Complex represents the only middle (Caradoc) to upper (Ashgill) Ordovician oceanic crust presently recognized in the Scandinavian Caledonides.

In this paper we present a brief review of the tectonostratigraphy and regional setting of the area as a basis for a more detailed discussion of the Sunnfjord Melange. The main structures in the Herland Group are interpreted in relation to the emplacement of the Solund-Stavfjord Ophiolite Complex. The timing of the obduction will be discussed within the framework provided by the geochronology and fossil occurrences in the area.

\section{Tectonostratigraphy and regional setting}

Brekke \& Solberg (1987) presented a discussion of the stratigraphy and tectonostratigraphy in the Sunnfjord area. Seven tectonostratigrapic units, initially established by Kolderup (1928), were redefined and subdivided into a Lower, Middle and Upper Tectonic Unit (Fig. 2). In the present study which deals primarily with the relationships between the Middle and Upper Tectonic Units, we introduce Sunnfjord Melange (SM) as a separate tectonostratigraphic unit. The SM is a disrupted terrane in the terminology of Jones et al. (1983) and provides a terrane-link between the continental rocks and their cover in the Middle Tectonic Unit and the oceanic rocks of the Upper Tectonic Unit which include the Solund-Stavfjord Ophiolite Complex and cover (Fig. 2).

\section{The Lower Tectonic Unit}

The Lower Tectonic Unit comprises the autochthonous gneisses of the Western Gneiss Region and the overlying highly deformed and heterogeneous rocks of both igneous and sedimentary origin in the Askvoll Group which has been described by Skjerlie (1969).

\section{The Middle Tectonic Unit}

The Middle Tectonic Unit comprises allochthonous continental basement and cover rocks of Precambrian to Silurian age and is separated from the Lower Tectonic Unit 


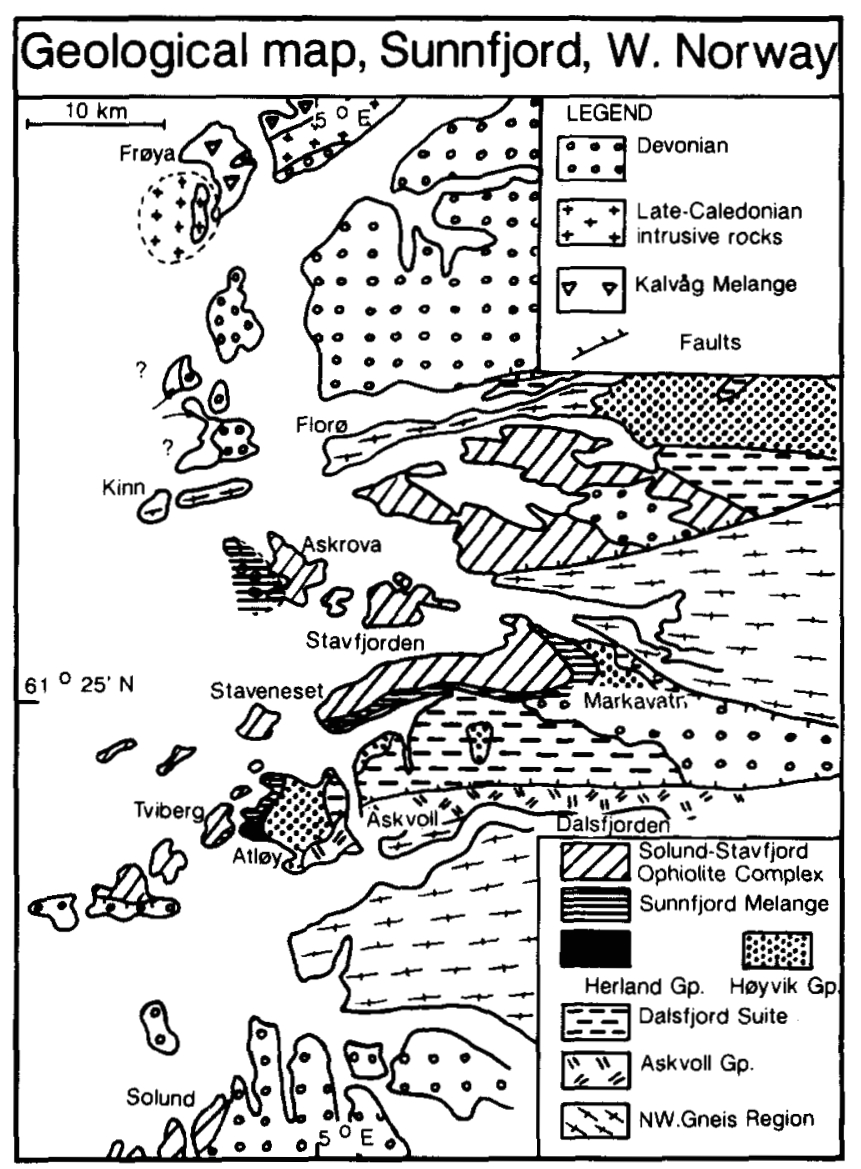

Fig. 1. Simplified geological map of the Sunnfjord area, showing the distribution of the main stratigraphical and structural units of the region.

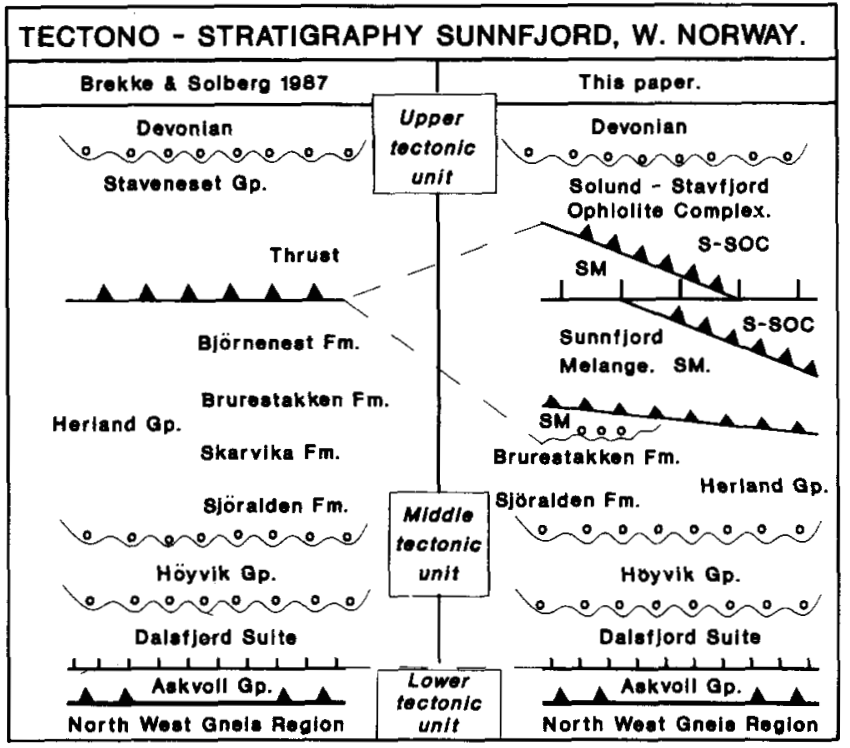

Fig. 2. Tectonostratigraphy in the Sunnfjord area based on Brekke \& Solberg (1987), and the present study. Wavy lines with cirlces represent unconformities. by a major structural discontinuity with a long and complex structural evolution, the Dalsfjord Fault. As here defined the Middle Tectonic Unit comprises three stratigraphic units: from base upwards (1) the Dalsfjord Suite with cover of (2) the Høyvik Group which is unconformably overlain by (3) the Herland Group.

The Dalsfjord Suite of intrusions and high-grade orthogneisses forms a continental basement to the unconformable metasedimentary sequence of the Høyvik Group. It includes anorthosites, mangerite-syenites, gabbros and granitic rocks (Kolderup 1921) which have been correlated by Milnes \& Koestler (1985) with the orthogneisses and intrusions of the Jotun Nappe in central south Norway (Fig. 3).

The stratigraphy of the Høyvik Group was established and described by Brekke \& Solberg (1987). It comprises a sequence dominated by metasandstones and mica schists, locally with marbles. In the uppermost part of the group a thin unit of highly deformed pillow lavas (Fig. 3) has recently been mapped by Dæhlin \& Andersen (pers. comm.). The rocks of the Høyvik Group were deformed and metamorphosed to upper greenschist facies, then eroded prior to the deposition of the unconformably overlying Herland Group. On the basis of its lithology, the geochemistry of the pre-tectonic dyke swarm which cuts the sediments and the resemblance of the Dalsfjord Suite to the rocks of the Jotun Nappe, the Høyvik Group has been correlated with the late Precambrian 'Sparagmites' (Fig. 3) of the Lower and Middle Allochthon in east-central Scandinavia (Andersen \& Dahlin 1986; Brekke \& Solberg 1987).

The Herland Group comprises a sequence of shelf sandstones, shales, conglomerates and limestones, which on Atløy display a single pervasive cleavage developed during lowermost greenschist facies metamorphism. Calcareous sandstones and limestones contain a shelly fauna which was first described by Reusch (1888). These fossils have been regarded as Ashgill or Llandovery (Skjerlie 1974; Brekke \& Solberg 1987). New finds of pentamerids, however, indicate that these rocks are of Wenlock age (M. Johnson, pers. comm.).

Brekke \& Solberg (1987) defined four formations within the Herland Group: the Sjøralden, Skarvika, Brurestakken and Bjørneneset Formations (Fig. 2). However, detailed sedimentological investigations in the type sections at Atløy by Berg (1988) show that a distinction between the rocks of the Sjøralden and Skarvika Formations was not necessary. They are thus grouped together here as the Sjøralden Formation. The succeeding Brurestakken Formation is retained in the Herland Group, but the Bjørneneset Formation shows such dramatic change in the depositional environment that Berg (1988) postulated that its lower boundary is tectonic. Consequently, he suggested that the Bjørneneset Formation was not part of the Herland Group.

The present investigation has shown that the contact between the Brurestakken and Bjørneneset Formations is a zone of high strain, but a preserved stratigraphic transition can be demonstrated locally. Nevertheless, we follow Berg (1988) in excluding the Bjørneneset Formation from the Herland Group and including it in the Sunnfjord Melange Unit, where the lowermost part of the Bjøneneset Formation represents the youngest part of the melange. This provides a temporal link between the formation of the SM and the fossiliferous sediments of the Herland Group. 


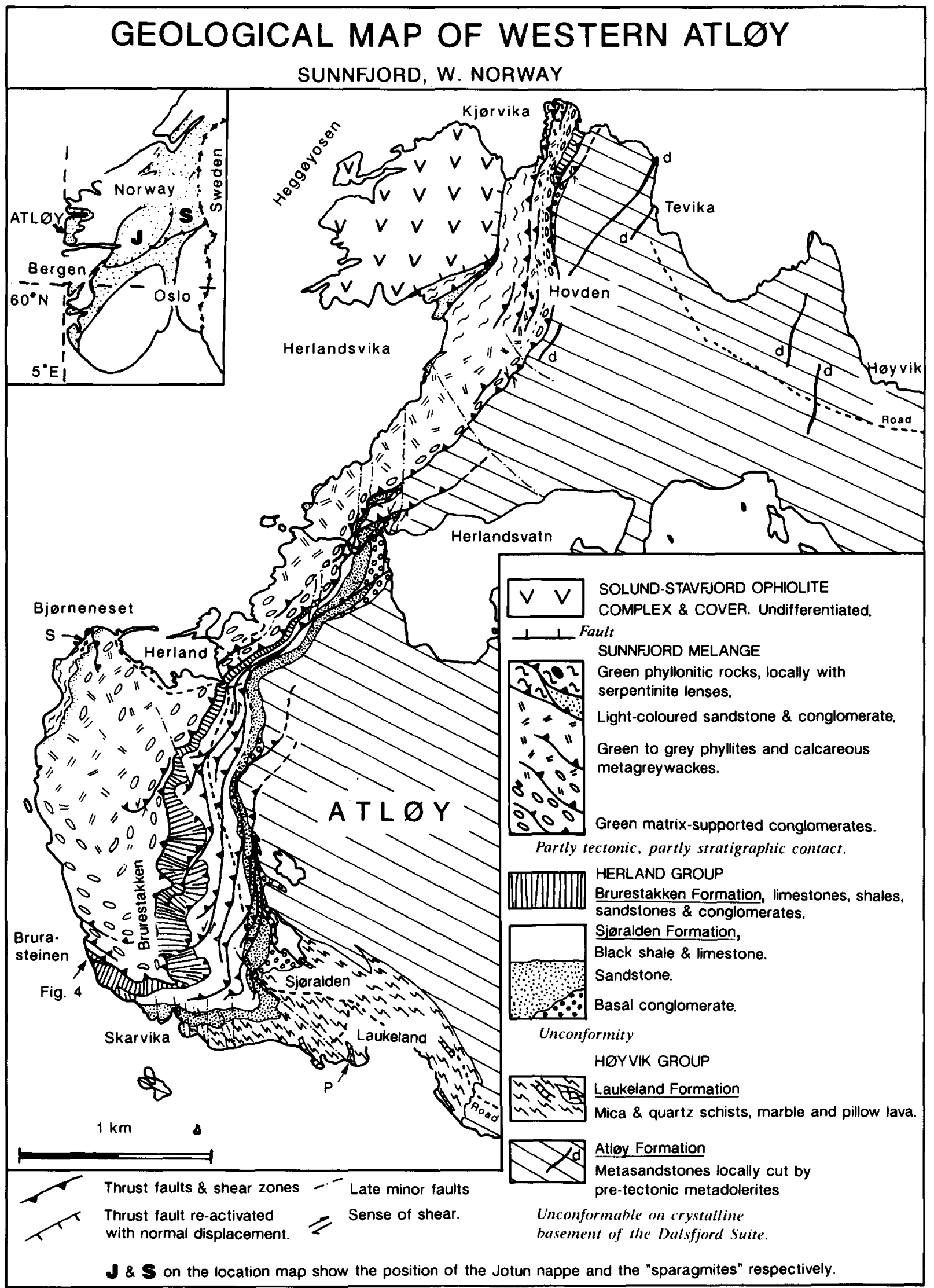

Fig. 3. Geological map of western Atløy. P shows locality for pillow lavas in the Laukeland Formation of the Høyvik Group. S shows localities for serpentinite lenses at Bjørneneset. 


\section{The Sunnfjord Melange Unit}

This composite unit contains fragments of a wide range of metasedimentary and igneous lithologies and occupies a tectonostratigraphic position between the Middle and Upper Tectonic Units of Brekke \& Solberg (1987). The lower contact of the continental margin deposits of the Middle Tectonic Unit is partly stratigraphic and partly tectonic. The upper contact with the ophiolite complex is in many areas marked by a late extensional fault, but this can be shown to mask an earlier thrust contact. The extensional fault pattern has been mapped in detail between Tviberg and Markavatn (Fig. 1). The main extensional fault, previously termed the Staveneset thrust by Brekke \& Solberg (1987), cuts mylonitic rocks believed to have developed in the upper part of the melange during the final emplacement of the ophiolite. Furthermore, on SW Tviberg the extensional fault(s) cut into the hanging wall of an older thrust contact between the ophiolite and the melange. Along most of the Staveneset peninsula (Fig. 1) the contact between the melange and the ophiolite complex is a major contractional shear zone developed between metagreywackes in the melange and greenstones and gabbros of the ophiolite.

\section{The Upper Tectonic Unit, the Solund-Stavfjord Ophiolite Complex and cover}

The regional distribution of the ophiolite complex and its cover is shown in Fig. 1. The lowermost exposed parts of the ophiolite contain some layered gabbro, but it is dominated by the upper part of the plutonic zone with variably-textured and isotropic gabbros which pass locally into diorite and sheeted dykes. Zircons from the diorite have yielded a concordant U-Pb age of $443 \pm 3 \mathrm{Ma}$ (Dunning \& Pedersen 1988). The high-level plutonic rocks on Tviberg are transected by two generations of cross-cutting dyke swarms. The older set strikes $060^{\circ}$ and the younger strikes $020^{\circ}$. Both dyke generations have MORB geochemistry (Skjerlie 1988) thought to represent magmatism associated with riftpropagation. Skjerlie et al. (1989) interpret the second set of dykes as the result of intrusion within a leaky transform or the propagation of a new rift with a new spreading direction.

The sea-floor spreading was accompanied by an abundant supply of greywacke sediments, resulting in the partial burial of the extrusions. Much of the subsequent basalt magma was then intruded as sills into the wet sediment. Pillow lavas are subordinate volumetrically to the sills.

In addition to the magmatism with MORBgeochemistry, some of the cover rocks on the ophiolite record a major development of basaltic pillow lavas and volcaniclastic material with an alkaline geochemical signature. The metasediments in the cover on the ophiolite in Sunnfjord are characterized by a thick sequence of calcareous metagreywackes and green volcaniclastic rocks. Abundant clasts of quartzite and mica schists in pebbly sandstones show that the provenance of the greywackes was continental. MORB magmatism contemporaneous with the rapid accumulation of thick, commonly coarse-grained greywackes shows that the sea-floor spreading occurred near a continent, most likely in a marginal basin (Skjerlie 1988).

\section{Stratigraphy, structure and geological evolution of the Sunnfjord Melange}

The melange comprises a number of tectonic slices and lenses which were assembled during the emplacement of the overriding ophiolite. As such it represents a tectonic melange where the individual slices record various stages of the accretion history from the sea-floor spreading stage to the final emplacement of the ophiolite onto the continent.

\section{The contact with the Middle Tectonic Unit}

The melange can be mapped as a separate unit from Tviberg in the south to Markavatn in the east, and further towards the northwest. It also occurs on a number of islets in the area to the west of the island of Askrova, but they have not been mapped in detail (Fig. 1). The best preserved parts of the melange occur in the Atløy-Tviberg area (Figs $1 \& 3$ ), which thus provides most of the critical localities for constraining the models, particularly with regard to the contact with the underlying Silurian Herland Group. As mentioned previously, this contact is characterized by high strains. A penetrative foliation is developed particularly in the calcareous phyllites of the Upper Limestone member of the Brurestakken Formation (Brekke \& Solberg 1987). This member, as well as similar calcareous phyllites and limestones lower in the Brurestakken Formation, and the shales in the Sjøralden Formation have acted as decollement horizons during the final emplacement of the ophiolite (Fig. 4). Locally, at Brurasteinen, a duplex with two horses of the Upper Conglomerate and Upper Limestone member of the Brurestakken Formation is present between the roof thrust below the Sunnfjord Melange and the floor thrust of the duplex which ramps up from the Lower Limestone member of the Brurestakken Formation (Fig. 5). Along the lower contact of the Sunnfjord Melange, from Brurestakken to Hovden (Fig. 4), the entire Herland Group is excized along the decollement horizon with the exception of minor pockets of the basal conglomerate in the Herland Group which have been locally preserved beneath the tectonic contact (Fig. 4). A penetrative shear fabric characterizes the contact zone between the Sunnfjord Melange and the Herland Group.

East of Kjørvika, however, the Brurestakken Formation reappears above a ramp in the footwall (Figs $3 \& 4$ ). At this point, the decollement at the base of the Sunnfjord Melange ramps up from a deeper stratigraphic level towards the hinterland. This geometry produces a stratigraphical repetition involving the Høyvik Group and puts older rocks on younger. In the hanging-wall above the ramp, a primary stratigraphic transition between light-coloured calcareous sandstones and vein-quartz conglomerates of the Brurestakken Formation and the green conglomerates in the lower part of the SM has been preserved. The stratigraphical contact between the SM and the Brurestakken Formation can be traced from the sea, approximately $350 \mathrm{~m}$ inland and around the hinge of a tight fold developed in the hanging wall above the ramp (Figs $3 \& 4$ ). The stratigraphical contact is characterized by a 1 to $2 \mathrm{~m}$ thick layer in which the pebbly sandstones and the conglomerate pebbles comprise light-coloured quartz-rich material. This clearly has a continental source similar to the Herland Group. The finer-grained material and matrix in the conglomerates have a greenish colour which is typical of the Sunnfjord Melange. Detailed mapping of the contact at this locality shows that 


\section{RESTORED, PRE D-3 VERTICAL SECTION,HERLAND AREA, WESTERN ATLØY.}

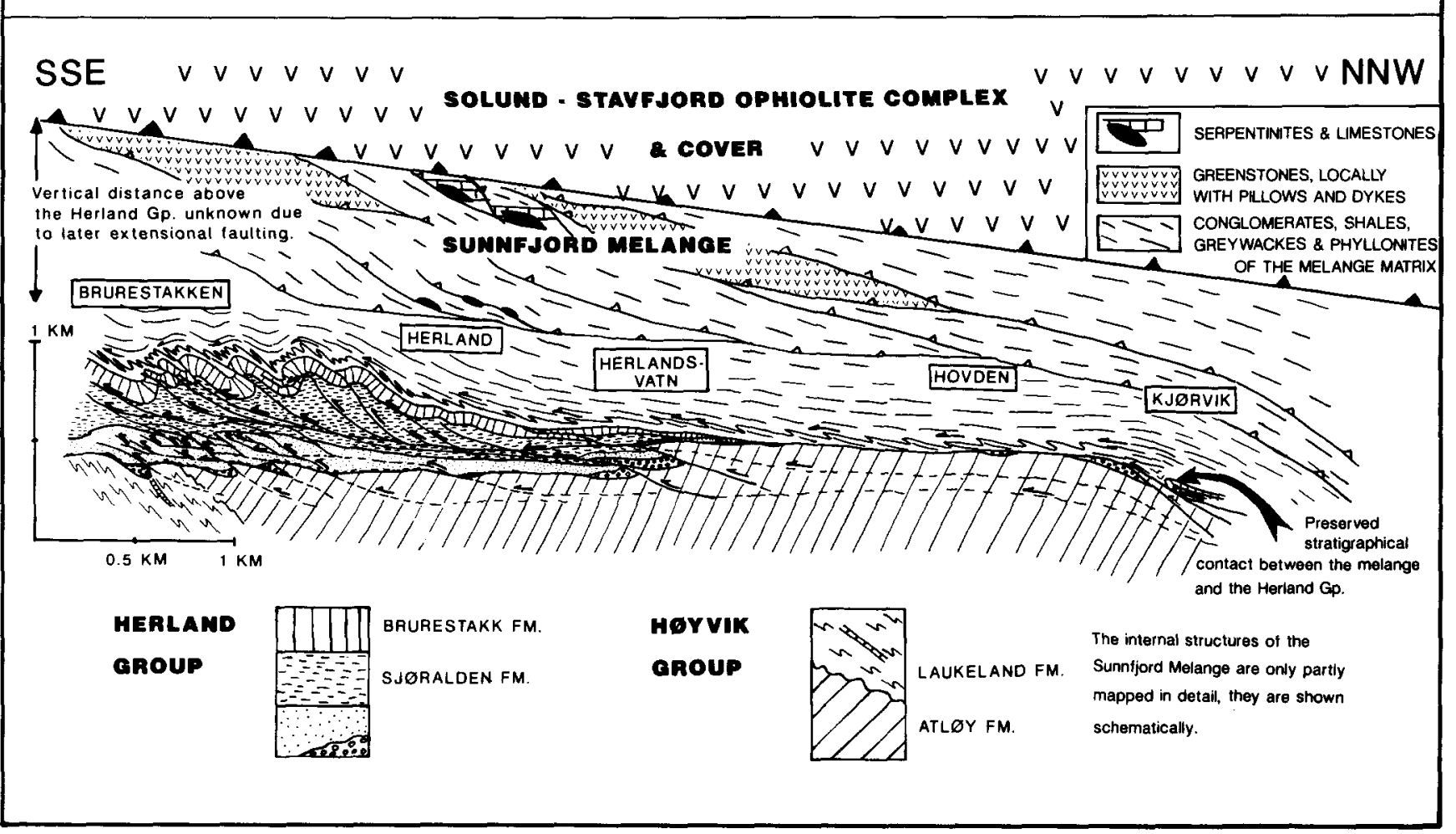

Fig. 4. Restored pre-D3 section of the western Atløy area. The section represents a near vertical profile, and shows the structural and stratigraphical relationships between the continental rocks of the Middle Tectonic Unit, the Sunnfjord Melange and the Solund-Stavfjord Ophiolite Complex. Note the thrust-foldbelt geometry in the Herland Group and that the basement of the Høyvik Group was involved in the deformation in the northern part of the section.

beds in the Brurestakken Formation are truncated by the basal layer of the melange and the contact represents a low-angle unconformity.

\section{Petrography}

The conglomerate units in the Sunnfjord Melange are characterized by green, thick-bedded, matrix-supported conglomerates, mud-shales and sandstones which have a pebble population dominated by quartzite, vein-quartz, limestones and jasper. A characteristic group of previously undeformed and unmetamorphosed sandstones is also common. Locally, at Staveneset, pebbles derived from mafic igneous rocks and quartz diorites are common (Skjerlie 1974). The continentally derived clasts are always well rounded, a characteristic which suggests that they have been re-deposited (Brekke \& Solberg 1987; Berg 1988). The metamorphic quartzites and vein-quartz pebbles may well have come from the Høyvik Group, while the previously undeformed sandstones may have been eroded from the Herland Group or laterally equivalent rocks as these sandstones had no fabric prior to the formation of the melange. The pebbles of jasper, mafic igneous rocks and the green matrix together with the material derived from the continental margin testify to a bimodal provenance for this part of the SM. A depositional mechanism in the form of submarine gravity flows has been suggested by Brekke \& Solberg (1987) and Berg (1988). The matrix-supported pebbly sandstones and mudshales probably represent debris flows. A deep marine environment at a base-of-slope setting has been suggested by Berg (1988).

The green chlorite-epidote-rich matrix of the conglomerate has a penetrative phyllitic cleavage. Apart from bedding which locally shows normal grading in sandstones, few primary structures are preserved in this part of the melange. A number of shear zones characterized by phyllonitic rocks occur within the conglomerates and greywackes, and the internal stratigraphy above the lower contact of the melange is therefore uncertain. Where grading is preserved, however, it indicates right way-up. At structurally higher levels in the best preserved sections between Brurasteinen and Herland (Fig. 3), the pebbles become more scattered and calcareous greywacke-type sandstones with a high content of shaly material dominate. These have a penetrative phyllitic cleavage. Local light-coloured pebbly sandstones and sandstones of dominantly quartzitic composition occur as layers and lenses at this level in the Sunnfjord Melange. The conglomerates of the melange become thinner towards the north from approximately $400 \mathrm{~m}$ in the Herland area to a total thickness of approximately $50 \mathrm{~m}$ across the foliation at Kjørvika (Fig. 3).

Further along strike to the northeast, the deformation has been more intense and all external and internal contacts in the SM are highly sheared and/or faulted. The characteristic conglomerates with a bimodal source can, however, be traced almost continuously to the Markavatn 


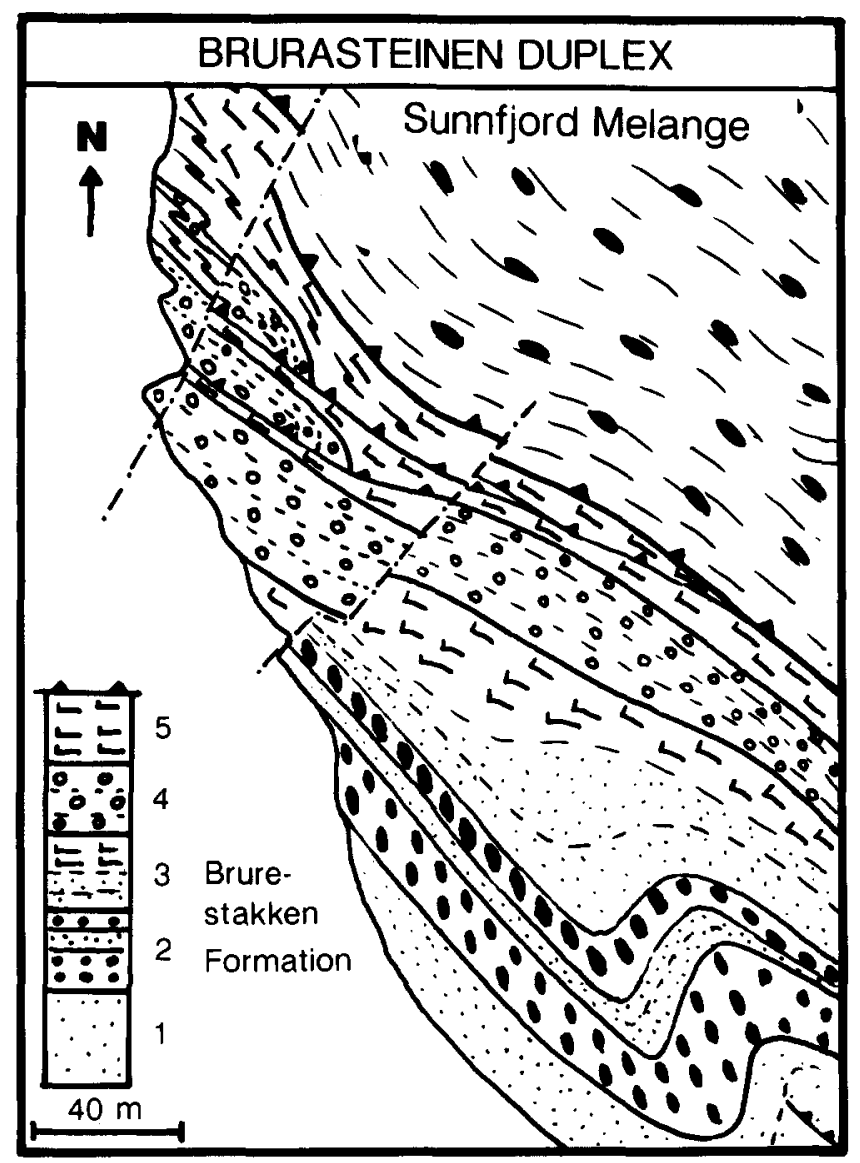

Fig. 5. Detailed map of the Brurasteinen duplex on western Atløy (see Fig. 3 for location). The dotted lines represent bedding internally in the stratigraphic units. Note that hangingwall cut-offs can be identified in the two horses of the quartzite conglomerate. (1) Sandstone. (2) Vein-quartz conglomerate with sandstone. (3) Dark sandstone, shale with calcareous shales and fossiliferous limestone at the top. (4) Quartzite conglomerate. (5) Dark sandstone, strongly foliated calcarous shales and limestone.

area (Skjerlie 1974). In this area serpentinite lenses several metres across occur in the conglomerate.

\section{Higher structural units in the Sunnfjord Melange}

The lithologies in the higher structural positions within the melange are strongly transposed in a composite S1-S2 foliation, and are juxtaposed in discontinuous structural slices bounded by anastomosing shear zones. This relation is shown schematically in Fig. 4. Several distinct structural slices can be identified in the Atløy-Tviberg area on the basis of internal petrographic variations.

\section{Lenses of greenstone}

Lenses of greenstone bounded by shear zones occur within the SM on Tviberg and Staveneset (Fig. 1). The largest lens occurs on Tviberg as an elliptical body more than $1 \mathrm{~km}$ long and $250 \mathrm{~m}$ wide bounded on all exposed sides by shear zones (Fig. 4). It includes well preserved sheeted dykes. A similar, but smaller $(\min 300 \mathrm{~m} \times 50 \mathrm{~m})$ lens occurs on eastern Tviberg. A body of pillow lavas more than $200 \mathrm{~m}$ long and $50 \mathrm{~m}$ wide with MORB composition (Furnes et al. 1988) occurs on Staveneset (Fig. 1). It has sheared margins like the other lenses, but internally pillow lavas are relatively well preserved.

\section{Greywackes and phyllites with fragments of ultramafic rocks}

A major part of the Sunnfjord Melange consists of green and grey calcareous metagreywackes and green phyllitic and phyllonitic rocks. Some dark green phyllitic shales shales with trace-element compositions similar to mafic and ultramafic rocks are interlayered with quartz-rich metagreywackes.

Unlike the sedimentary cover on the Solund-Stavfjord Ophiolite Complex, the sedimentary rocks of the Sunnfjord Melange lack syn-sedimentary mafic igneous rocks. Locally, however, serpentinite and talc-schist lenses occur. These may vary in size from few centimetres to approximately $5 \mathrm{~m}$. Shear zones lubricated by soapstone have developed along some of the larger fragments, but a number of small isolated lenses indicate that the serpentinites were original fragments deposited in a shale-greywacke matrix. West of Herland, at Bjørneneset (Fig. 3), a number of ultramafic fragments occur. In this area they are associated with small (up to $1 \mathrm{~m}$ ) fragments of limestone with a characteristic yellow to orange colour. Similar ultramafic fragments and talc-schist shear zones occur on Staveneset in the lower parts of the SM and in the conglomerates at Markavatn (Fig. 1).

The lens of pillow lava on Staveneset descirbed above is underlain by conglomerates. Structurally above the pillow lava block are calcareous meta-greywackes, locally with conglomerate horizons and sheared serpentinites and talc-schists (Osmundsen \& Andersen pers. comm.). On Tviberg, the greenstone lenses are structurally overlain by a characteristic unit with lenticular bodies and blocks of detrital serpentinite sandstones, talc-pebble conglomerates, limestones and greenstones. These occur as blocks in a highly sheared green phyllonitic matrix (Fig. 4). By analogy with modern ocean conditions (Bonatti et al. 1983; Saleeby 1984), Skjerlie (1988) and Skjerlie et al. (1989) argue that the detrital ultramafic rocks were formed by erosion of serpentinite protrusions at the oceanic stage. The model explains the limestones as reefs that formed around such protrusions which reached shallow marine environments. An oceanic transform or fracture zone is suggested as the most probable environment for the formation of this rock association. Similar limestones and ultramafic rocks occur discontinuously along strike to the Markavatn area. Large $(>500 \mathrm{~m})$ and small $(5 \mathrm{~cm})$ lenses of ultramafic rocks are also present in the Sunnfjord Melange on the small islands west of Askrova where they occur together with greenstones and garnet-grade micaschists and metagreywackes (Fig. 1).

\section{The thrust-fold geometry of the Herland Group, a structural response to the emplacement of the Solund-Stavfjord Ophiolite Complex}

The sedimentary succession in the Herland Group represents continental margin deposits of Silurian age. They accumulated on a continental massif which had experienced an earlier orogeny, presumably of older Caledonian age (Brekke \& Solberg 1987; Berg 1988).

The structural pattern in the Herland Group records two main events (Andersen et al. 1988). The first event was 

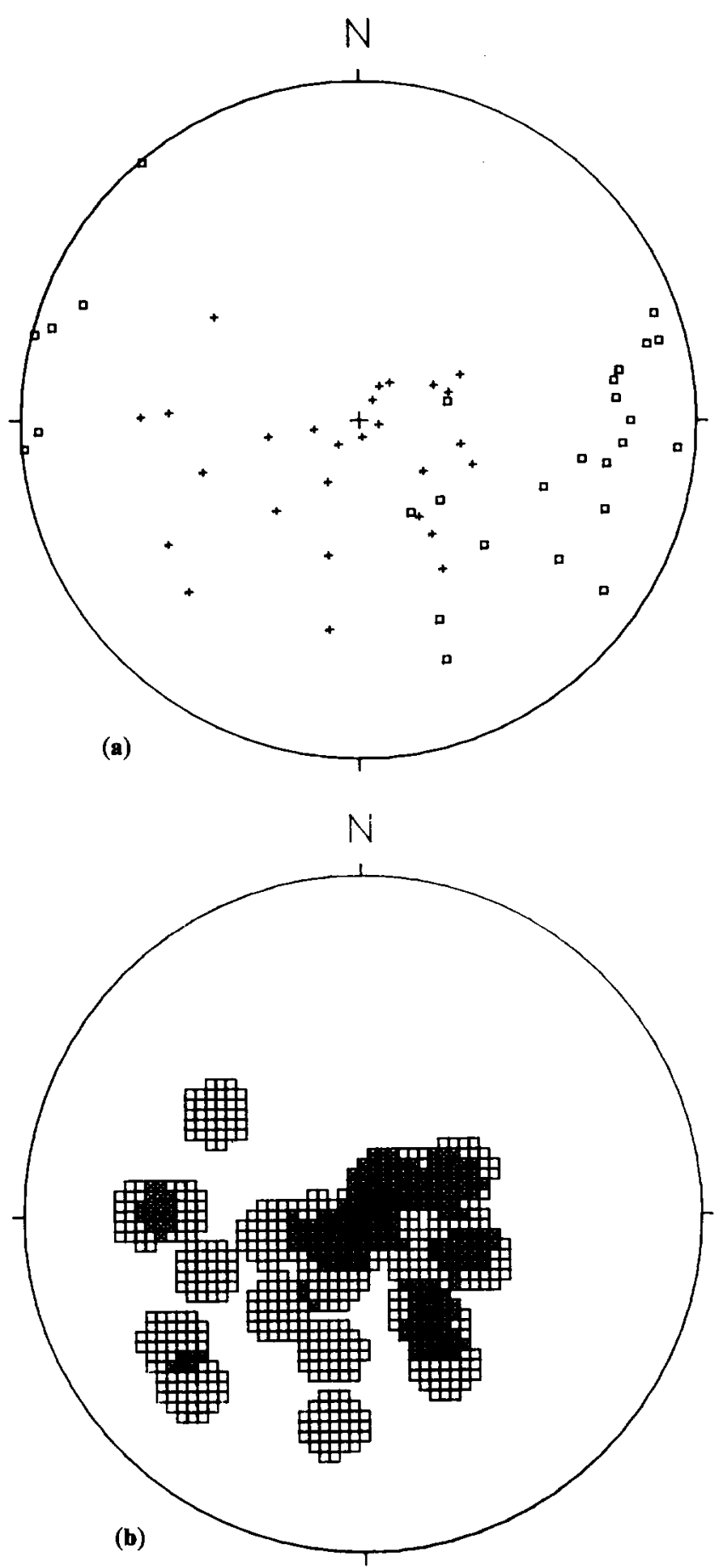

Fig. 6. (a) Equal area stereographic projection of poles to bedding in the Herland Group on the eastern steeply dipping limb of the Brurestakken F3 fold in the area between Sjøralden and Brurestakken (see Fig. 3). Squares are poles to the present (post-D3) orientation. Crosses represents the pre D3 orientation when unfolded $70^{\circ}$ around the axis $015^{\circ}-20^{\circ}$ of the Brurestakken F3 fold. (b) Contoured equal area projection of unfolded poles to bedding (crosses in a), illustrating the predominant sub-horizontal orientation of the bedding prior to the F3 folding: Max. concentration $20 \%, 27$ poles plotted.

associated with southeasterly directed compressional tectonics previously described as D1 and D2 (Brekke \&
Solberg 1987). The second event included westerly directed back-folding (D3), ductile re-activation of thrusts and brittle normal faulting associated with late- to post-Caledonian extension of the Caledonian Nappe pile. The most prominent structures developed during the west-verging second event are the spectacular asymmetric Brurestakken fold (Fig. 3) and the extensional faults in the melange zone. The D3 back-folding is responsible for the steep dips (Fig. 6a) of the earlier planar structures between Brurestakken and Kjørvika. The present map provides a near vertical section through the structures as they developed after the first compressional event (Fig. 4). Because the late west-verging folds and faults post-date the ophilite emplacement, they are of little importance in the present discussion and not discussed further. When the steep limb of the Brurestakken fold is unfolded around the F3 axis, the poles to the bedding in the Brurestakken-Sjøralden area have a predominantly sub-horizontal orientation (Fig. 6b).

\section{Layer-parallel shortening of the Herland Group}

The compressional structures in the Herland Group which are related to the southeasterly directed tectonic transport are variably developed in different lithologies. All rocks in the area have developed an early cleavage (S1). In the sandstones of the Sjøralden Formation this cleavage is a spaced pressure-solution cleavage. The internal strains in the sandstones outside the cleavage domains are small. Due to the low strain, the sedimentary structures in this unit show excellent preservation. The cleavage in the sandstones of the Sjøralden Formation generally had a northeasterly dip at a slightly higher angle than the gently dipping bedding prior to the westerly directed back-folding.

Shaly horizons in the sandstones have acted as shear planes. During the progressive deformation, a large number of minor faults with 'stair-case' trajectory developed in the sandstones (Fig. 4). The shaly partings in the sandstones acted as flats, while the pressure solution cleavage lamellae were utilized as frontal ramps. In the less competent calcareous and black shales (Sjøralden and Brurestakken Formations), the $S 1$ cleavage is a composite $S-C$ foliation which demonstrates that layer-parallel shearing and décollement thrusting were localized in the shaly horizons. The relationships between the $S$ and $C$ planes show that the tectonic transport was to the southeast. Penetrative stretching lineations related to this thrusting are locally developed in conglomerates in both the Sjøralden and the Brurestakken Formations.

A major decollement zone occurs in the Skarvika shale member of the Sjøralden Formation (Fig. 4). When traced towards the hinterland this shear zone has a trailing branch point with the main shear zone beneath the Sunnfjord Melange west of Herlandsvatn. Similar decollement horizons formed in the shaly limestone members of the Brurestakken Formation and branches from the same zone west of Herlandsvatn (Figs 3 \& 4). A duplex formed where the decollement in the Lower Limestone member ramps up to the decollement beneath the SM at Brurasteinen (Fig. 5). The competent sandstones and conglomerates which are interlayered with shaly limestones in the overlying Brurestakken Formation experienced layer-parallel shortening by folding. Initial concentric folds with geometry controlled by the competent layers were later modified by flattening and break-thrusts ramping up from the thickened 
shales in the Sjøralden Formation as the layer-parallel shortening could no longer be taken up the concentric folds (Fig. 4). These folds had gently plunging to sub-horizontal fold axes with an WSW-ENE orientation prior to the asymmetric back-folding (D3). The folds have previously been assigned to an F2 generation (Brekke \& Solberg 1987). This was based on the observation that the $S 1$ folation is folded by these folds. In the present model, however, this folding is taken to represent a continuous development of the SE directed thrusting. The folds formed by ductile, layer-parallel shortening in the hanging wall and have only locally an axial planar foliation (S2).

The geometric constraints for balancing of profiles is not satisfied in the present case. A very rough estimate based on the shortening of the basal layer of the Brurestakken Formation, however, indicates approximately $30 \%$ shortening $(930 \mathrm{~m})$ over a distance of $3.1 \mathrm{~km}$ in the least deformed area between Brurestakken and Herlandsvatn (Fig. 4).

\section{A model for obduction of the Solund-Stavfjord Ophiolite Complex}

The Silurian sedimentary rocks of the Herland Group represent continental margin sediments which were deposited on a continent comprising Precambrian continental crust similar to that of the Jotun Nappe. The age, sedimentology and westerly sediment dispersal shown by palaeocurrents indicate that the Herland Group was part of a passive continental margin on the western side of this continent (Berg 1988) until middle Silurian times. The tectono-metamorphic and stratigraphic hiatus between the Herland and Høyvik Groups (Brekke \& Solberg 1987) shows that the underlying continental rocks had experienced an earlier orogenic phase, probably of Caledonian age. The development of the relatively thin (approximately $300 \mathrm{~m}$ ) continental margin deposits in the lower to middle Silurian was interrupted intermittently by syn-depositional faulting on the margin which resulted in an abundant resedimentation of the coarse clastic material of the Herland Group (Berg 1988).

The oldest known rocks in the Solund-Stavfjord Ophiolite Complex in this area have been dated at $443 \pm 3 \mathrm{Ma}$ (Pedersen \& Dunning 1988), an age which straddles the Caradoc-Ashgill boundary in the time-scale of McKerrow et al. (1985). Field and petrological studies in the ophiolite (Skjerlie 1988; Skjerlie et al. 1989) show that spreading-related magmatism continued after the dated rocks had formed. The younger MORB-basalts were produced in a propagating rift with a dyke orientation of $020^{\circ}$ as opposed to the older with an orientation of $060^{\circ}$. The cover sequence to the ophiolite includes thick sequences of metagreywackes from a continental source. Several observations from the ophiolite and its cover indicate that a transform system was developed in the area at the oceanic stage (Skjerlie 1988; Skjerlie et al. 1989). Some of the large lenses and blocks bounded by shear zones in the SM have internal characteristics which indicate that they formed in a transform fracture zone environment. We suggest that the site of the original obduction may have been initiated along a former transform valley which served as a sediment trap for the thick sequences of turbidites characteristic of the cover sequence (Fig. 7).

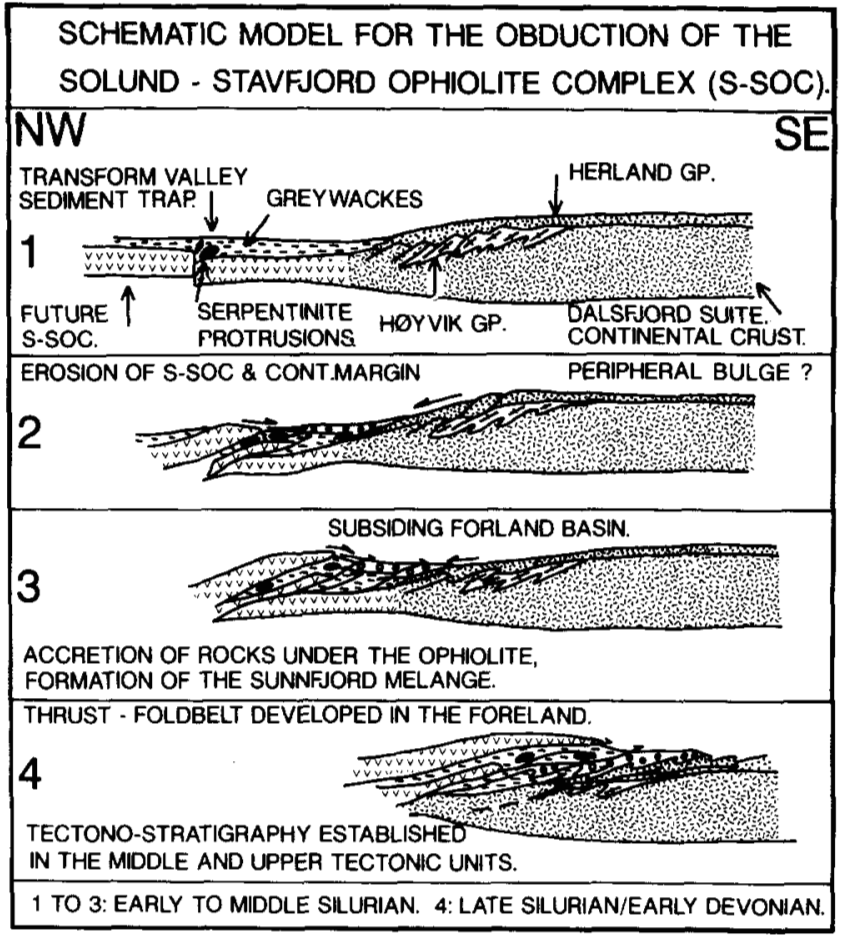

Fig. 7. A reconstruction (not to scale) of the Silurian ophiolite obduction.

The collapse of the continental margin with formation of the structurally lowermost conglomerates in the Sunnfjord Melange occurred after deposition of the limestones and calcareous shales in the uppermost part of the Brurestakken Formation. These rocks stratigraphically overlie the rocks with Pentamerids of probable Wenlock age. As shown above, the conglomerates in the melange have locally preserved a stratigraphic transition to the Herland Group. Overstepping of stratigraphic units in the Herland Group by the conglomerates of the melange in the Kjørvika area indicates that this contact was a low-angular angular unconformity as suggested by Brekke \& Solberg (1987). Due to the subsequent deformation, it is difficult to establish this relationship on a regional scale with certainty.

The relationships between the Solund-Stavfjord Ophiolite Complex, the Sunnfjord Melange and the Herland Group show that the time span between the formation of the oldest parts of the ophiolite and the melange is in the order of 15 to 20 million years based on the time-scale of McKerrow et al. (1985). In comparison with obduction and emplacement of other ophiolites, it is a reasonable time span for the obduction-emplacement event. The formation of the Bay of Islands ophiolite in Newfoundland has been dated at $486 \pm 3 \mathrm{Ma}$. (U-Pb on zircons, Dunning \& Krogh 1985) and the obduction as shown by the dating of the metamorphic sole is $460 \pm 5 \mathrm{Ma}\left({ }^{40} \mathrm{Ar} /{ }^{39} \mathrm{Ar}\right.$ on amphibole, Dallmeyer \& Williams 1975). This gives a time gap between spreading and obduction of $26 \pm 8$ Million years. An unconformity at the Arenig-Llanvirn boundary is interpreted to date the formation of a peripheral bulge in the carbonate platform sequence in Newfoundland (Stenzel written comm. in Cawood et al. 1988). The bulge developed as a result of loading of the distal parts of the miogeocline. Taking the Arenig-Llanvirn boundary at $470 \mathrm{Ma}$ as 
suggested by McKerrow et al. (1985) and the formation of the Bay of Islands ophiolite at $486 \pm 3 \mathrm{Ma}$ (Dunning \& Krogh 1985) the time span between formation to obduction may be as short as $16 \pm 3$ million years. A similar time span of 20 million years has been suggested between the spreading stage and the obduction of the Semail ophiolite in Oman (Searle \& Malpas 1980; Lippard 1983).

Our model for Silurian obduction of the SolundStavfjord Ophiolite Complex suggests that the obduction was initiated along a plane of weakness in the ocean-floor which may have been a fracture zone related to a transform fault (Fig. 7-1). A full discussion of this will be presented elsewhere. The Sunnfjord Melange represents a disrupted terrane containing large blocks and lenses from different parts of the ophiolite. These blocks may partly represent olistoliths because some of the ultramafic blocks clearly represent pebbles and boulders in conglomerate. Tectonic emplacement as thrust slices is, however, probable for some of the large greenstone lenses (Figs $4 \& 7-2$ ). During the Silurian obduction, the ophiolite loaded the passive continental margin and major redeposition of the continental margin deposits in the Herland Group was initiated. The final collapse of the margin was associated with rapid subsidence and development of a foreland basin in which the submarine mass-flow deposits accumulated (Figs 7-2 \& 7-3). These were accreted to the base of the melange during the continued convergence which produced the thrust-fold belt structural geometry in the Herland Group. The continental margin deposits of the Herland Group experienced decollement thrusting, associated folding and layer-parallel shortening during the final emplacement of the ophiolite (Fig. 7-4).

\section{General conclusions}

The ophiolitic terranes within the Norwegian Caledonides have been described in a variety of publications during last decade. A two-fold division of the ophiolites into Groups I and II was suggested by Furnes et al. (1981) and the model was elaborated and discussed in more detail by Sturt et al. (1984). In this model the Group I ophiolites were of Cambrian or older age and had been obducted onto the Baltic miogeocline during a late Cambrian-early Ordovician orogeny (Sturt 1984). Unconformable transgressive sequences are the most important evidence of early deformation of Group I ophiolites. On the basis of stratigraphical arguments from the Trondheim area, the Group II ophiolites were thought to be of Middle Ordovician age (Furnes et al. 1985).

At the present time, no direct evidence of the timing or location of the obduction of Group I ophiolites can be demonstrated. They cannot have been involved in the early Caledonian tectono-thermal history (510 to $490 \mathrm{Ma})$ affecting rocks in the Seve Nappe Complex (Dallmeyer \& Gee 1986; Mørk et al. 1988) because this event pre-dated the oldest dated ophiolites (Dunning \& Pedersen 1988). Hence, the Solund-Stavfjord Ophiolite Complex represents the first ophiolite within the Scandinavian Caledonides where the accretion can be accurately determined in both time and space.

We conclude that the Sunnfjord Melange represents a disrupted terrane developed during ophiolite obduction. The precise $\mathrm{U}-\mathrm{Pb}$ dating of zircons from the SolundStavjford Ophiolite Complex at $443 \pm 3 \mathrm{Ma}$ together with the Silurian fossils in the Herland Group provide the time-frame of the model. The structural and stratigraphical relationships between the Herland Group, the Sunnfjord Melange and the Solund-Stavfjord Ophiolite Complex provide the necessary constraints for the model.

We thank F. Skjerlie for stimulating discussions on the geology in Sunnfjord. H. Brekke set the scene for the current investigations by his identification of the unconformities on Atløy. Valuable contributions to the understanding of the area have been made by our students P. Chr. Dæhlin, T. Karlsen and P. T. Osmundsen. One of the referees and the editor have suggested a number of improvements to the manuscript. Funding was received from NAVF, project D. 41.31.147. This study is a Norwegian ILP-contribution Nr. 73.

\section{References}

Andersen, T. B. \& Daehlin, P. Chr. 1986. Basement-cover kontakten mellom Høyvikguppen og Dalsfjordsuiten på Atløy, en pre-kaledonsk avsetningskontakt. (Abstract). Geolognytt 21, 13.

- SkJerle, K. P. \& Furnes, H. 1988. Den tidlige deformasjonen i Herlandgruppen, Atløy; et forland skyve-foldebelte utviklet under Silurisk ofiolitt obduksjon. (Abstract). Geolognytt 22, 14.

BERG, T. 1988. Sedimentology of the Herland Group on Atloy, Sunnfjord, Western Norway. Unpublished Cand. Scient. thesis University of Bergen.

Bonatt, E., Clocchiatti, R., Colantoni, P., Gelmin, R., Marinelli, G. Ottenello, G., Santacroce, R., Taviani, M., Abdel-Meguid, A. A., AssaF, H. S. \& EL TAHIR, M. A. 1983. Zarbargad (St. John's) Island: an uplifted fragment of sub-Red Sea lithosphere. Journal of the Geological Society, London, 140, 677-690.

BrekKe, H. \& Solberg, P. O. 1987. The geology of Atløy, Sunnfjord western Norway. Norges geologiske Undersøkelse, Bulletin, 410, 73-94.

Cawood, P. A., Williams, H., O'Brian, S. J. \& O'Neill, P. P. 1988. Trip Al. Geological cross-section of the Appalachian orogeny. Field trip guidebook. Geological Association of Canada. St. John's 1988.

DAllmeYer, R. D. \& GEE, D. G. $1986 .{ }^{40} \mathrm{Ar} /{ }^{39} \mathrm{Ar}$ mineral dates from retrogressed eclogites within the Baltoscandian miogeocline. Implications for a polyphase Caledonian orogenic evolution. Bulletin of the Geology Society of America, 97, 26-34

- \& Williams, H. $1975 .{ }^{40} \mathrm{Ar} /{ }^{39} \mathrm{Ar}$ ages for the Bay of Islands metamorphic aureole: their bearing on the timing of Ordovician ophiolite obduction. Canadian Journal of Earth Sciences, 12, 1685-1690.

DunNING, G. R. \& KROGH, T. E. 1985. Geochronology of ophiolites of the Newfoundland Appalachians. Canadian Journal of Earth Sciences, 22, 1659-1670.

—_ \& Pedersen, R. B. 1988. U/Pb ages of ophiolites and arc-related plutons of the Norwegian Caledonides: implciations for the development of Iapetus. Contributions to Mineralogy and Petrology, 98, 13-23.

Furnes, H., Ryan, P. D., Grenne, T., Roberts, D., Sturt, B. A. \& Prestvik, T. 1981: Geological and geochemical classification of the ophiolite fragments in the Scandinavian Caledonides. (Abstract). Terra Cognita, 1, 43.

- , Ryan, P. D., Grenne, T., Roberts, D., Sturt, B. A. \& Prestrik, T. 1985. Geological and geochemical classification of the ophiolite fragments in the Scandinavian Caledonides. In: GEE, D. G. \& STURT, B. A. (eds) The Caledonide Orogen-Scandinavia and related areas. Wiley, New York., 657-670.

—, Skjerle, K. P., Pedersen, R. B., Andersen, T. B., Skjerlie, F. J., Stillman, C. J. \& Tysseland, M. 1988. Solund-Stavfjorden ofiolittkompleks og assosierte bergarter (Vest-norske Kaledonider): Magmatiske produkter og tektonisk miljø. (Abstract). Geologyntt. 22.

Jones, D. L., Howell, D. G., Coney, P. J. \& Monger, J. W. H. 1983. Recognition, character and analysis of tectonostratigraphic terranes in western North America. In: Hashimoto, M. \& UYEDA, S. (eds) Accretionary tectonics in the circum-Pacific Regions. Advances in Earth and Planetary Sciences. Terra Science Publishing Co., Tokyo. 21-35.

Kolderup, N. H. 1921. Der Mangeritsyenit und umgebende Gesteine zwischen Dalsfjord und Stavfjord in Søndfjord im westlischen Norwegen. Bergen Museum Ärbok, 1920-21.

— 1928. Fjellbygningen i kyststrøket mellom Nordfjord og Sognefjord. Bergen Museum Arbok. 1928. Natur Vitenskapelig rekke Nr. 1.

LipPard, S. J. 1983. Cretaceous high pressure metamorphism in NE Oman and its relationship to subduction and ophiolite nappe emplacement. Journal of the Geological Society, London, 140, 97-104.

McKerrow, W. S., Lambert, R. ST. J. \& Cocks, L. R. M. 1985. The Ordovician Silurian and Devonian Periods. In: Snelling, N. J. (ed.) The 
Chronology of the Geological Record. Geological Society, London, Memoir, 10, 73-80.

Mitnes, A. G. \& KoestLer, A. G. 1985. Geological structure of Jotunheim, southern Norway (Sognefjell-Valdres cross-section). In: GEE, D. G. \& StURT, B. A. (eds) The Caledonide Orogen-Scandinavia and related areas. Wiley, New York, 457-474.

Mørk, M. B. E., Kullerud, K. \& Stabel, A. 1988. Sm-Nd dating of Seve eclogites, Norrbotn, Sweden-Evidence for early Caledonian (505 Ma) subduction. Contributions to Mineralogy and Petrology, 99, 344-351.

ReusCH, H. 1988. Forsteninger i Søndfjords fjelde. Naturen, 4, 122.

SALEEBY, J. B. 1984. Tectonic significance of serpentinite mobility and ophiolitic melange. Geological Society of America, Special Paper, 198, 153-168.

Searle, M. P. \& Malpas, J. 1980. Structure and metamorphism of the rocks beneath the Semail ophiolite of Oman and their significance in ophiolite obduction. Transactions of the Royal Society of Edinburgh, Earth Sciences, 71, 247-262.

SkJERLIE, F. J. 1969. The pre-Devonian rocks in the Askvoll-Gaular area and adjacent districts, Western Norway. Norges geologiske Undersøkelse, Bulletin, 258, 325-359.

1974. The Lower Palaeozoic sequence of the Stavfjorddistrict, Sunnfjord. Norges geologiske Undersøkelse, Bulletin, 302, 1-32.

SKJERLIE, K. P. 1988. Geologiske relasjoner mellom gabbro og gangkompleks, petrogenese og tektonomagmatisk modellurvikling $i$ omrädet Tviberg $-N V$. Atloy, Solund-Stavfjorden Ofiolittkompleks. Cand. Scient. thesis. University of Bergen.

- Furnes, H. \& Johansen, R. J. 1989. Magmatic development and tectono-magmatic Models for the Solund-Stavfjorden Ophiolite Complex, W. Norwegian Caledonides. Lithos, (in press).

Sturt, B. A. 1984. The accretion of ophiolitic terrains in the Scandinavian Caledonides. Geologie en Mijnbouw, 63, 201-212.

- RoberTs, D. \& Furnes, H. 1984. A conspectus of Scandinavian Caledonian ophiolites. In: Gass, I. G., LipPard, S. J. \& Shelton, A. (eds): Ophiolites and oceanic lithosphere. Geological Society London, Special Publication, 13, 381-391.

Received 23 December 1988; revised typescript accepted 31 March 1989. 